\title{
Growth Characteristics of Calves Fed an Intensified Milk Replacer Regimen with Additional Lactoferrin ${ }^{1}$
}

\author{
K. E. Cowles, ${ }^{*}$ R. A. White, $\nmid$ N. L. Whitehouse,‡ and P. S. Erickson $\ddagger^{2}$ \\ *Dept. of Animal Sciences, University of Illinois, Urbana 61801 \\ †Puyallup Research and Extension Center, Washington State University, Puyallup, 98371 \\ ‡Department of Animal and Nutritional Sciences, University of New Hampshire, Durham 03824
}

\begin{abstract}
The objective of this study was to evaluate the effect of lactoferrin addition to milk replacer varying in crude protein $(\mathrm{CP})$ on dry matter intake, growth, and days medicated. Thirty-four Holstein heifer calves were assigned to 4 treatments in a $2 \times 2$ factorial arrangement of treatments in a randomized complete block design. Treatments were as follows: $562 \mathrm{~g}$ daily of a nonmedicated conventional milk replacer (20\% CP:20\% fat) feeding regimen with or without $1 \mathrm{~g}$ of supplemental bovine lactoferrin ( $\mathrm{n}=9$ for both treatments) or a nonmedicated intensified milk replacer feeding regimen $(28 \%$ CP:20\% fat) fed on a metabolizable energy basis $(0.2$ $\mathrm{Mcal} / \mathrm{kg} \mathrm{BW}^{0.75}$ ) from d 2 to 9 , and at $0.27 \mathrm{Mcal} / \mathrm{kg}$ $\mathrm{BW}^{0.75}$ from d 10 to 42 with or without $1 \mathrm{~g}$ supplemental bovine lactoferrin ( $\mathrm{n}=8$ for both treatments). Calves were fed pelleted starter (25\% CP) in 227.5-g increments beginning on $\mathrm{d} 2$ and had free access to water. Calves remained on the study for $14 \mathrm{~d}$ postweaning. Dry matter intake was determined daily. Growth measurements were taken weekly. Blood samples were taken twice weekly for determination of blood urea $\mathrm{N}$. On d 10 of life, calves were subjected to a xylose challenge. Calves on conventional treatments ate more starter preweaning, during weaning, and postweaning. Preweaning, intensively fed calves had higher dry matter intakes. Weights of intensified-fed calves were greater at weaning. Intensified milk replacer-fed calves had greater average daily gain preweaning and overall and higher gain:feed ratios preweaning, but conventionally fed calves had higher gain:feed ratios during weaning. Intensified milk replacer-fed calves had greater hip heights during weaning and postweaning and greater heart girths preweaning, weaning, and postweaning. Days medicated were greater preweaning and overall for intensified-fed calves. There were no
\end{abstract}

Received March 21, 2006.

Accepted July 24, 2006.

${ }^{1}$ This is Scientific Contribution Number 2294 from the New Hampshire Agricultural Experiment Station.

${ }^{2}$ Corresponding author: peter.erickson@unh.edu differences among treatments for xylose absorption. Calves on conventional treatments had increased blood urea nitrogen concentrations preweaning. There were no effects of lactoferrin on any experimental variable. Intensified milk replacer-fed calves consumed less starter but had higher average daily gains overall and larger frames and greater BW than conventionally fed calves. An intensified milk replacer feeding regimen promotes faster growth during the preweaning period when compared with calves fed conventional treatments, but supplemental bovine lactoferrin was not beneficial under these experimental conditions.

Key words: milk replacer, lactoferrin, calf

\section{INTRODUCTION}

Fifty percent of dairy heifers in the United States are fed milk replacer (MR; NAHMS, 1996). Recently, researchers developed a MR that more closely resembles whole milk than traditional MR (Diaz et al., 2001). Conventional MR typically comprises whey proteins and animal fat. Crude protein content is usually $20 \%$, and fatty acid content typically ranges from 15 to $22 \%$ (DM basis). The newly developed MR contains $28 \% \mathrm{CP}$ (primarily from whey proteins) and $20 \%$ fat, and is fed at a higher rate (Diaz et al. 2001). Calf performance on this program has resulted in greater $\mathrm{ADG}$, skeletal growth, and lean muscle mass (Tikofsky et al., 2001; Blome et al., 2003). Although these calves consumed more MR, questions remain regarding starter consumption, rumen development, and weaning. Davis and Drackley (1998) suggested that replacement calves should be fed a restricted liquid diet to encourage dry feed intake, thereby allowing weaning to occur as early as possible. It is well established that calves need fermentable carbohydrates and fiber, which are found in starter grain, to produce VFA for rumen epithelial development and establish microbial populations (Greenwood et al., 1997). A calf fed large amounts of liquid feed may eat less starter, thereby delaying rumen development and weaning.

Due to increasing pressure to reduce subtherapeutic use of antibiotics in animal agriculture, there is a need 
to investigate possible alternatives. Lactoferrin $(\mathbf{L F})$ is a $78-\mathrm{kDa}$ iron-binding protein that exhibits broadspectrum antimicrobial effects. Lactoferrin is found in colostrum, milk, and tears (Kijlstra et al., 1983), cerebrospinal fluid (Talukder et al., 2003), and most other body secretions. Lactoferrin concentrations are highest in bovine colostrum $(2 \mathrm{mg} / \mathrm{mL}$; Masson and Heremans, 1971). It is an effective antimicrobial agent against a wide range of infectious agents, such as Escherichia coli (Reiter and Perraudin, 1998), Salmonella spp., and Staphylococcus spp. (Weinberg, 2001).

Joslin et al. (2002) observed that calves fed either 1 or $10 \mathrm{~g} / \mathrm{d}$ of LF had higher BW, increased ADG, tended to consume more dry feed, and tended to have increased feed efficiency (gain:DMI) compared with calves receiving no LF. Robblee et al. (2003) observed that calves supplemented with $1 \mathrm{~g} / \mathrm{d}$ of $\mathrm{LF}$ added to $\mathrm{MR}$ had reduced fecal scores and number of days medicated compared with nontreated calves. Average daily gain and feed efficiency were increased in calves fed $1 \mathrm{~g} / \mathrm{d}$ of LF during the preweaning phase compared with calves on other treatments.

Lactoferrin in colostrum may serve several purposes to the newborn calf; it may offer protection from infection, stimulate carbohydrate absorption (Teraguchi et al., 1998), and increase small intestine epithelial cell size (Zhang et al., 2001). A D-xylose absorption test is an indirect measure of intestinal absorptive capacity. Several studies have included xylose tests on young calves to evaluate intestinal function (Hammon and Blum, 1997; Kuhne et al., 2000; Rauprich et al., 2000).

The objectives of this study were to evaluate intensified calf feeding on starter intakes, performance, and parameters indicating rumen development and to observe the performance, health, and intestinal function of calves fed $1 \mathrm{~g} / \mathrm{d}$ of bovine LF supplementation preweaning.

\section{MATERIALS AND METHODS}

\section{Calves, Diets, and Treatments}

This experiment was reviewed and approved by the University of New Hampshire Institutional Animal Care and Use Committee.

At birth, 34 Holstein heifers (initial BW of $43.1 \pm 5.3$ $\mathrm{kg}$ ) were randomly assigned by blocks of 4 to 1 of 4 treatments: nonmedicated conventional (20\% CP: $20 \%$ fat,) MR with (CL) or without (C0) $1 \mathrm{~g}$ of supplemental bovine $\mathrm{LF}$ ( $\mathrm{n}=9$ each group); or nonmedicated intensified MR (28\% CP: $20 \%$ fat) with (IL) or without (I0) 1 $\mathrm{g}$ of supplemental bovine LF ( $\mathrm{n}=8$ each group). The number of calves was limited by calf availability. The source of LF was bovine milk (Immucell Corp., Portland, ME); iron saturation was $13.2 \mathrm{~g} / 100 \mathrm{~g}$. All calves received $2 \mathrm{~L}$ of good quality colostrum (mean $\operatorname{IgG}=73.9$ $\mathrm{mg} / \mathrm{dL} \pm 15.6$ ) tested by a colostrometer within $3 \mathrm{~h}$ of birth, and another $2 \mathrm{~L}$ within $12 \mathrm{~h}$. A $50-\mathrm{mL}$ aliquot of colostrum was saved and stored at $-20^{\circ} \mathrm{C}$ for IgG and LF analyses using radial immunodiffusion assay (RID; Cardiotech, Louisville, KY). Calves were removed from their dam before the first feeding of colostrum and placed in individual pens $(1 \mathrm{~m} \times 2.15 \mathrm{~m})$ in a naturally ventilated, enclosed calf room. Pens were bedded with kiln-dried sawdust. The calves remained in their pens for the duration of the study.

An initial BW, wither height, hip height, heart girth, and hip width were taken by $24 \mathrm{~h}$ after birth. Calves were trained to consume MR from a bucket after the colostrum-feeding period. On d 1 , calves were fed 2.27 $\mathrm{kg}$ of whole milk at 0700 and $1500 \mathrm{~h}$. On d 2, calves began on their respective treatments.

\section{Feed intake and Analysis}

All calves had free-choice access to a nonmedicated, pelleted starter (Archer Daniels Midland, Inc., Ft. Wayne, IN) and fresh water for the duration of the study. The starter was experimental and consisted of grain, plant protein, fat, vitamins, minerals, and molasses. Fresh starter was fed once daily in the morning. The starter was offered in 227.5-g increments; when a calf consumed $227.5 \mathrm{~g}$, she was offered more starter. Starter orts were collected and weighed daily. Calves on $\mathrm{C} 0$ and CL treatments received $562 \mathrm{~g}$ of MR daily, reconstituted at $15 \% \mathrm{DM}$, split into 2 feedings. This remained constant until $\mathrm{d} 42$. Calves on the I0 and IL treatments were fed based on ME requirements. From d 2 to 9 , calves were fed MR to meet an intake of 0.2 $\mathrm{Mcal} / \mathrm{kg}$ of BW $\mathrm{BW}^{0.75}$. From d 10 to 42 , calves were fed to meet an intake of $0.27 \mathrm{Mcal} / \mathrm{kg}$ of $\mathrm{BW}^{0.75}$ (Tikofsky et al., 2001). All calves were weaned following the same protocol; calves were switched to one morning MR feeding on $\mathrm{d} 42$ for $7 \mathrm{~d}$, and then were weaned completely at $\mathrm{d} 49$. Calves remained on the study for $14 \mathrm{~d}$ postweaning for a total of $63 \mathrm{~d}$ on the study.

Dry matter intake was calculated on a daily basis. The DM of the orts was determined daily, and the DM of starter and MR powder was determined for each 22.7$\mathrm{kg}$ bag. The DM of the orts was determined by drying in a forced-air convection oven (VWR Scientific Products Corp., Boston, MA) for $6 \mathrm{~h}$ at $60^{\circ} \mathrm{C}$. A sample from each day was ground through a 1-mm screen using a Wiley mill (Thomas Scientific, Swedesboro, NJ) and composited into preweaning and postweaning periods for nutrient analysis. The DM of the MR powder and starter was determined by drying samples in the same forcedair convection oven at $60^{\circ} \mathrm{C}$ for $24 \mathrm{~h}$. Samples from each bag of MR (50 g) and starter were saved and stored at 
Table 1. Nutrient analyses of milk replacer (MR) and starter on a DM basis ${ }^{1}$

\begin{tabular}{|c|c|c|c|}
\hline Item & $\begin{array}{l}\text { Conventional } \\
\mathrm{MR}^{2}\end{array}$ & $\begin{array}{l}\text { Intensified } \\
\mathrm{MR}^{3}\end{array}$ & Starter ${ }^{4}$ \\
\hline $\mathrm{DM}(\%)$ & 96.2 & 97.1 & 92.2 \\
\hline $\mathrm{CP}(\%)$ & 20.5 & 27.4 & 25.6 \\
\hline $\operatorname{RDP}^{5}(\%)$ & - & - & 16.3 \\
\hline $\operatorname{RUP}^{5}(\%)$ & - & - & 8.6 \\
\hline Fat $(\%)$ & 19.67 & 20.2 & 11.1 \\
\hline $\operatorname{NDF}(\%)$ & - & - & 4.3 \\
\hline $\mathrm{Ca}(\%)$ & 0.92 & 0.87 & 1.01 \\
\hline $\mathrm{P}(\%)$ & 0.97 & 0.91 & 0.55 \\
\hline $\mathrm{Mg}(\%)$ & 0.18 & 0.18 & 0.31 \\
\hline $\mathrm{Fe}(\mathrm{mg} / \mathrm{kg})$ & 100 & 117 & 250 \\
\hline
\end{tabular}

${ }^{1}$ The protein in the MR was from milk sources and the fat was animal fat.

${ }^{2}$ Conventional MR contained 77,000 IU/kg of vitamin A, 7,700 IU/ $\mathrm{kg}$ of vitamin D, and $331 \mathrm{IU} / \mathrm{kg}$ of vitamin E.

${ }^{3}$ Intensified MR contained 22,000 IU/kg of vitamin A, 3,850 IU/kg of vitamin D, and $149 \mathrm{IU} / \mathrm{kg}$ of vitamin $\mathrm{E}$.

${ }^{4}$ The starter grain contained 14,600 IU/kg of vitamin A, 3,890 IU/ $\mathrm{kg}$ of vitamin D, and $112 \mathrm{IU} / \mathrm{kg}$ of vitamin E.

${ }^{5} \mathrm{RDP}$ and RUP values provided by Archer Daniels Midland Inc., Ft. Wayne, IN.

$-20^{\circ} \mathrm{C}$. When the experiment was completed, samples were composited for nutrient analysis. Composited starter samples $(75 \mathrm{~g} / \mathrm{bag})$ were dried in the forced-air convection oven at $60^{\circ} \mathrm{C}$ for $6 \mathrm{~h}$. Composites of starter were ground through a 1-mm screen using a Wiley mill. Milk replacer and starter were analyzed for CP (AOAC, 1979), fatty acid or fat content (AOAC, 1995), and $\mathrm{Ca}$, $\mathrm{P}, \mathrm{Mg}$, and $\mathrm{Fe}$ (AOAC, 1990), and $\mathrm{LF}$ after reconstituting the milk replacer to 15\% DM (RID; Cardiotech). Milk replacer was analyzed for intake energy by an adiabatic bomb calorimeter (Parr Instruments Co., Moline, IL). Starter was analyzed for NDF (Goering and Van Soest, 1970). Chemical analysis of MR and starter are shown in Table 1. Lactoferrin content of the intensified and control MR was $1.19 \pm 0.04 \mathrm{mg} / \mathrm{g}$ of $\mathrm{DM}$ and $0.45 \pm 0.01 \mathrm{mg} / \mathrm{g}$ of $\mathrm{DM}$, respectively. These amounts of LF consumed fall within the range of LF fed in the studies of Joslin et al. (2002) and Robblee et al. (2003). The maximum amount of LF consumed in this experiment was $2.6 \mathrm{~g} / \mathrm{d}$ at the highest consumption observed for the IL treatment. Average LF content of colostrum was $1.12 \pm 0.15 \mathrm{~g} / \mathrm{L}$.

\section{Measurements and Blood Samples}

Calves were weighed and measured for wither height, hip height, heart girth, and hip width once weekly for the duration of the trial. Calves were weighed on a platform scale (Salter Scales, Fairfield, NJ). Wither and hip heights were taken with a sliding-scale height stick with a bubble level. Heart girths were measured using a weigh tape, and hip widths were measured using a
Hip-O-Meter (Dairy Innovations, Attica, NY). Calves born on Friday through Monday were weighed and measured on the following Monday, and every Monday thereafter at $1000 \mathrm{~h}$. Calves born on Tuesday through Thursday were weighed and measured the following Thursday and every Thursday thereafter at $1000 \mathrm{~h}$. Evaluation of fecal consistency was performed by 3 independent scorers every Monday, Wednesday, and Friday. All of the scorers were blind to treatment. Feces were scored on a scale of 1 through 4 , with $1=$ firm and 4 = watery diarrhea (Robblee et al., 2003). Rectal temperatures were determined in calves that appeared ill (listless, dull, failure to eat, or had diarrhea). Medication was given to calves that had a rectal temperature of $39^{\circ} \mathrm{C}$ or above. Days medicated were recorded as each day a calf received medication.

\section{Blood Collection}

Blood was collected from all calves twice weekly on Mondays and Thursdays before weights and measurements were taken. Blood was collected via jugular venipuncture using 5 -mL evacuated tubes. Tubes without anticoagulant were used for the determination of BUN and were stored at $4^{\circ} \mathrm{C}$ for $1 \mathrm{~h}$ before centrifugation. Blood was centrifuged at $3,300 \times g$ for $20 \mathrm{~min}$. Supernatants were divided into aliquots and stored at $-20^{\circ} \mathrm{C}$ until analyzed.

On d $10( \pm 1 \mathrm{~d})$, D-xylose $(0.5 \mathrm{~g} / \mathrm{kg}$ of BW) was fed to each calf by adding it to the MR at the a.m. feeding. Blood samples were taken before $(0 \mathrm{~h})$ and $0.5,1,2,3$, $4,6,8$, and $12 \mathrm{~h}$ after feeding. Calves were fasted for entire blood sampling time, but were allowed access to free-choice water. Blood samples were collected via jugular venipuncture into evacuated tubes containing $15 \%$ tripotassium EDTA to measure D-xylose and glucose concentrations in the plasma.

\section{Blood Analyses}

Blood urea $\mathrm{N}$ concentration was determined using Procedure No. 535 (Sigma Chemical Co., St. Louis, MO). Serum IgG concentration from 24-h samples was determined using RID (Cardiotech). D-Xylose and glucose concentrations were measured in blood samples collected on d 10 of life. Plasma D-xylose concentration was measured as described by Merritt and Duelly (1983). Plasma glucose concentration was determined using a glucose oxidase based kit (Wako, Richmond, VA).

\section{Statistical Analyses}

A randomized complete block design was used; calves were randomly assigned to treatment in blocks of 4 
based on birth order. An ANOVA was conducted using the MIXED procedure of SAS (SAS Institute, 2001). The mixed effects model used was as follows:

$$
Y_{i}=\mu+B_{i}+L_{j}+M_{k}+L M_{j k}+C_{i j k l}+e_{i j k l}
$$

where $Y_{i}$ is the dependent continuous variable, $\mu$ is the overall mean, $B_{i}$ is the random effect of block ( $\left.i=1, \ldots 9\right)$, $\mathrm{L}_{\mathrm{j}}$ is the fixed effect of lactoferrin source $(\mathrm{j}=0,1), \mathrm{M}_{\mathrm{k}}$ is the fixed effect of milk replacer source $(\mathrm{k}=20, \ldots 28)$, $\mathrm{LM}_{\mathrm{jk}}$ is the fixed effect of the interaction between the jth lactoferrin source and the kth milk replacer source, $\mathrm{C}_{\mathrm{ijkl}}$ is the value of the covariate variable for the lth calf of the ith block of jth lactoferrin and kth milk replacer source $(1=1,34)$, and eijkl is the random residual $\sim \mathrm{N}$ $\left(0, \sigma^{2}\right)$

Data were run through 3 covariance structures: unstructured, compound symmetry, and first order autoregressive. First order autoregressive was the covariance structure selected due to smaller Bayesian information criteria values. Initial $\mathrm{BW}$ was used as a covariate for DMI and weight calculations, and initial skeletal measurements were used as covariates for the respective measurement. Initial blood values were used as covariates for each hour for glucose and xylose concentrations. Significance was determined at a probability value of 0.05 . Degrees of freedom were determined using the Sattherwaite option of the MIXED procedure of SAS (SAS Institute, 2001). One calf was removed from the final statistical analysis due to an allergic reaction to penicillin at wk 5 .

\section{RESULTS}

Milk replacer intake, starter intake, and total DMI is presented in Table 2 and Figures 1 and 2. Calves fed the intensified treatments had greater MR intake over the entire treatment period (Table $2, P<0.001$ ). There was an effect of MR on starter intake during the entire experiment except during wk 1 and 2. Calves on conventional treatments consumed more starter than calves fed intensified treatments (Figure 1). Similarly, there was an effect of MR on total DMI during the entire experiment but not during weaning (Table 2, Figure 2). There was a trend $(P<0.10)$ during the preweaning period for calves fed CL to consume more DM than calves fed C0, but calves fed I0 consumed more DM than those fed IL.

There was an effect of MR at weaning on BW. Calves fed intensified treatments had higher ADG than those fed conventional treatments (Table 3; Figure 3, $P<$ $0.001)$. There was a trend for intensified-fed calves to be heavier preweaning than calves fed control MR ( $P$ $<0.10)$. There were no differences in BW postweaning.
Preweaning, weaning, and overall ADG were higher for intensified-fed calves than calves fed conventional treatments (Table 3, Figure 3). There were no differences postweaning. Lactoferrin had no effect on BW, $\mathrm{ADG}$, and $\mathrm{ADG}$ per DMI.

There was a MR effect on preweaning and weaning ADG per DMI (Table 3, Figure 4). Calves on intensified treatments were more efficient preweaning than conventionally fed calves $(P<0.01)$, but calves on conventional treatments were more efficient during weaning than intensified-fed calves $(P<0.001)$. There were no differences postweaning and overall.

There were no significant differences for withers heights. There was a trend during weaning; calves receiving $\mathrm{LF}$ were taller than calves not receiving $\mathrm{LF}$ ( $P$ $<0.10$; Table 4). Intensified MR-fed calves were taller at the hip than conventionally fed calves during weaning and postweaning $(P<0.05$; Table 4$)$. There was a MR effect preweaning $(P<0.01)$, weaning $(P<0.001)$, and postweaning $(P<0.05)$ for heart girth; intensifiedfed calves had larger heart girths than conventionally fed calves (Table 4). There was also an MR effect on hip width during weaning $(P<0.01)$ and postweaning $(P<0.05)$; intensified-fed calves had larger hip widths than conventionally fed calves. There was a preweaning trend $(P<0.10)$ for intensified-fed calves to have larger hip widths than conventionally fed calves (Table 4).

There was a postweaning interaction $(P<0.05)$ for daily withers height gain; $\mathrm{C} 0$ calves had larger daily increases in withers height than CL calves, and IL calves had larger daily withers height increases than calves on I0 treatment. There was an interaction trend $(P<0.10)$ for overall daily withers height gain, with calves on $\mathrm{C} 0$ having greater withers height gains than calves on CL treatments, and IL calves had larger daily withers height gains than I0 calves. There were no treatment effects on hip height gain or heart girth gain. There was a preweaning trend $(P<0.10)$ for daily hip width gain to be larger for intensified-fed calves than conventionally fed calves. There also was a trend $(P<$ 0.10 ) for an interaction for overall daily hip width gain, with CL calves having similar gains as compared with $\mathrm{C} 0$, and I0 calves having greater hip width gains than IL.

There was a preweaning $(P<0.05)$ MR effect on days medicated, with conventionally fed calves having fewer days medicated than intensified-fed calves (Table 5). Control calves also had fewer days medicated overall than intensified-fed calves $(P<0.05)$. There was no treatment effect on fecal scores preweaning, postweaning and overall. There was an MR effect during weaning on fecal scores, with intensified-fed calves having lower fecal scores than calves receiving the conventional treatments $(P<0.05)$. There was no effect of LF. 
Table 2. Milk replacer (MR) intake, starter intake, and total DMI for calves fed $2 \mathrm{MR}$ varying in CP content with or without $1.0 \mathrm{~g} / \mathrm{d}$ of bovine lactoferrin preweaning

\begin{tabular}{|c|c|c|c|c|c|c|c|c|}
\hline \multirow[b]{2}{*}{ Item } & \multicolumn{4}{|c|}{ Treatment $^{1}$} & \multirow[b]{2}{*}{ SEM } & \multicolumn{3}{|c|}{ Contrast $^{2}$} \\
\hline & $\mathrm{C} 0$ & CL & I0 & $\mathrm{IL}$ & & $\mathrm{LF}$ & MR & INT \\
\hline \multicolumn{9}{|l|}{ MR intake (g/d) } \\
\hline Wk 1 & 562 & 562 & 740 & 712 & 23.6 & NS & $<0.001$ & NS \\
\hline Wk 2 & 562 & 562 & 998 & 852 & 35.8 & NS & $<0.001$ & NS \\
\hline Wk 3 & 562 & 562 & 1,125 & 1,125 & 28.0 & NS & $<0.001$ & NS \\
\hline Wk 4 & 562 & 562 & 1,209 & 1,209 & 33.4 & NS & $<0.001$ & NS \\
\hline Wk 5 & 562 & 562 & 1,342 & 1,322 & 34.9 & NS & $<0.001$ & NS \\
\hline Wk 6 & 562 & 562 & 1,358 & 1,300 & 41.8 & NS & $<0.001$ & NS \\
\hline Wk $7^{5}$ & 281 & 281 & 784 & 721 & 26.4 & NS & $<0.001$ & NS \\
\hline \multicolumn{9}{|c|}{ Starter intake (g/d) } \\
\hline Prewean & 385 & 419 & 211 & 129 & 41.1 & NS & $<0.001$ & NS \\
\hline Wk 7 (weaning) & 1,247 & 1,266 & 718 & 553 & 102.9 & NS & $<0.001$ & NS \\
\hline Postwean & 1,927 & 1,926 & 1,666 & 1,503 & 96.9 & NS & $<0.001$ & NS \\
\hline Overall & 823 & 848 & 591 & 481 & 51.9 & NS & $<0.001$ & NS \\
\hline \multicolumn{9}{|l|}{ Total DMI (g/d) } \\
\hline Prewean & 932 & 970 & 1,287 & 1,215 & 40.8 & NS & $<0.001$ & 0.08 \\
\hline Wk 7 (weaning) & 1,443 & 1,484 & 1,398 & 1,160 & 116.0 & NS & NS & NS \\
\hline Postwean & 1,927 & 1,926 & 1,666 & 1,503 & 96.4 & NS & $<0.001$ & NS \\
\hline Overall & 1,202 & 1,236 & 1,413 & 1,266 & 57.3 & NS & 0.009 & NS \\
\hline
\end{tabular}

${ }^{1}$ Treatments: $\mathrm{C} 0=$ conventional $\mathrm{MR}, \mathrm{CL}=$ conventional $\mathrm{MR}+1 \mathrm{~g} / \mathrm{d}$ of lactoferrin, $\mathrm{I} 0=28 \% \mathrm{CP} \mathrm{MR}$, and $\mathrm{IL}=28 \% \mathrm{CP} \mathrm{MR}+1 \mathrm{~g} / \mathrm{d}$ of lactoferrin.

${ }^{2}$ Contrasts: $\mathrm{LF}=$ lactoferrin vs. no lactoferrin; $\mathrm{MR}=$ conventional $\mathrm{MR}$ vs. $28 \% \mathrm{CP} \mathrm{MR}$; and INT = interaction.

Preweaning, there was an MR effect $(P<0.05)$ on BUN, with intensified-fed calves having lower values than conventionally fed calves (Table 6). There was a postweaning $\mathrm{LF}$ trend $(P<0.10)$ for BUN, with calves that had received LF having higher BUN concentrations than those not receiving LF (Table 6).

There were no differences in xylose absorption among treatments. There were no differences in area under

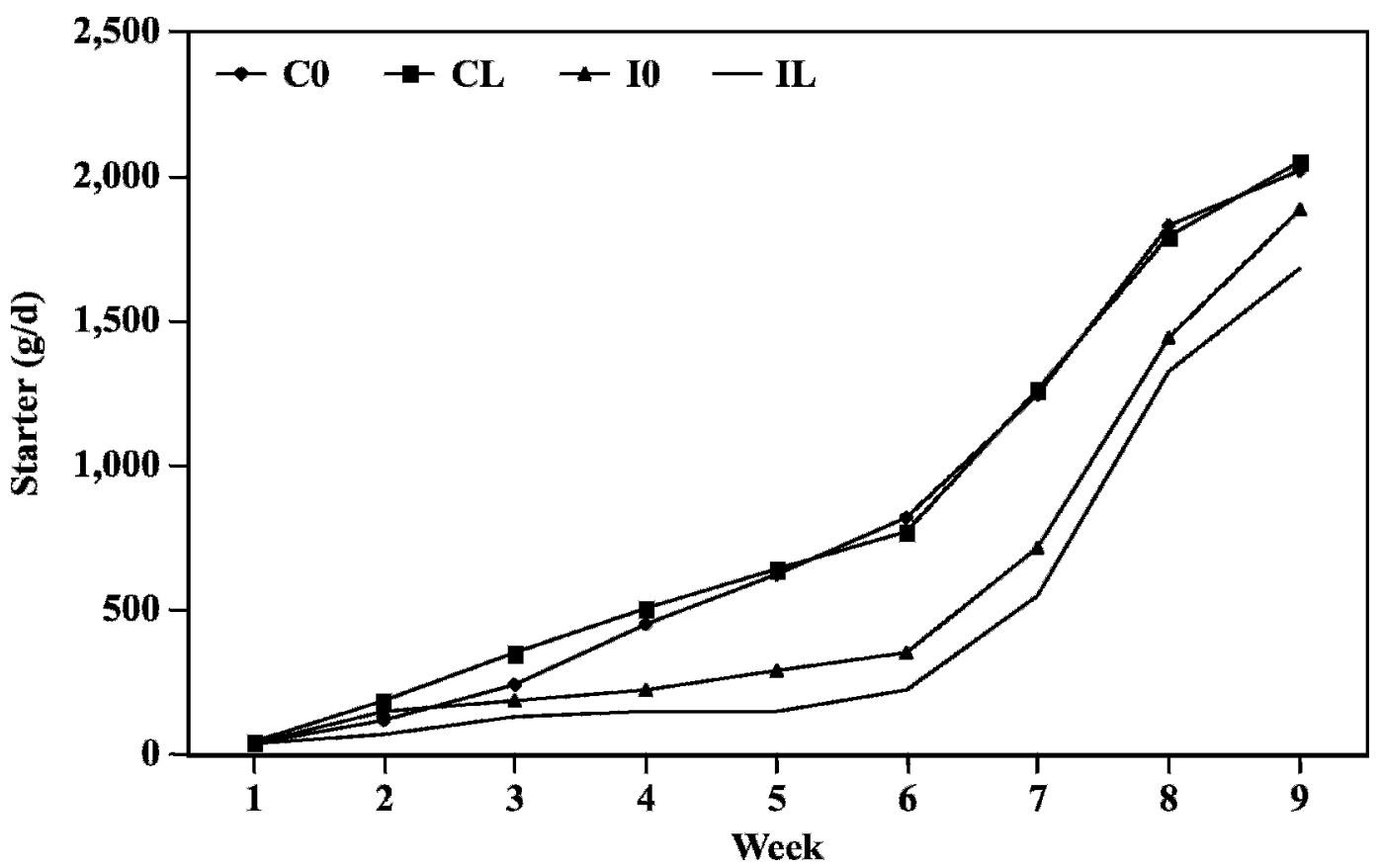

Figure 1. Starter intake of calves fed 2 milk replacers (MR) varying in CP content with or without $1.0 \mathrm{~g} / \mathrm{d}$ of lactoferrin preweaning. The largest SEM was $104 \mathrm{~g}$ during wk $9 . \mathrm{C} 0=$ conventional MR, CL = conventional MR $+1 \mathrm{~g} / \mathrm{d}$ of lactoferrin, $\mathrm{I} 0=28 \% \mathrm{CP} \mathrm{MR}$, and IL = $28 \% \mathrm{CP} \mathrm{MR}+1 \mathrm{~g} / \mathrm{d}$ of lactoferrin. 


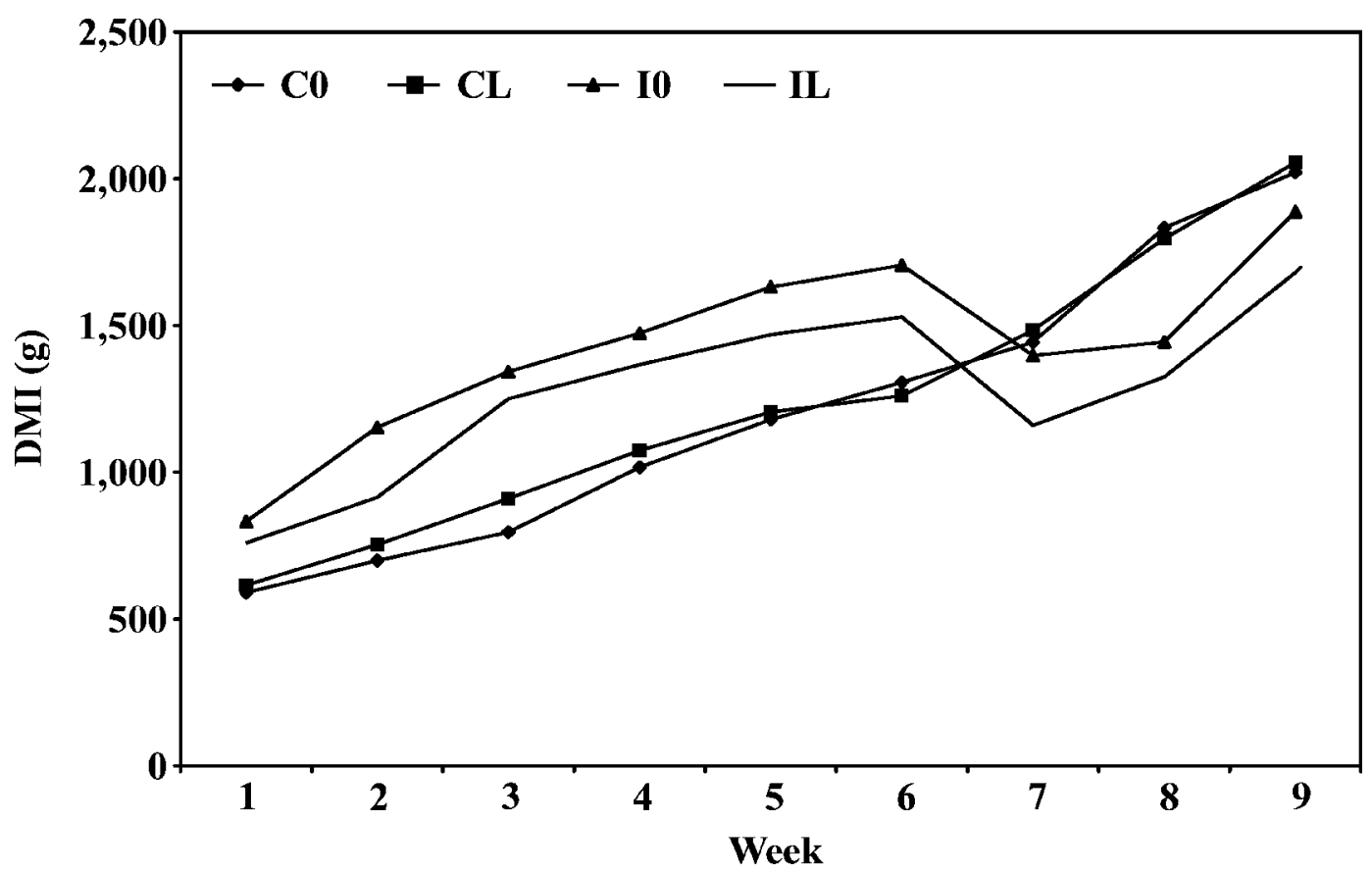

Figure 2. Dry matter intake of calves fed 2 milk replacers (MR) varying in CP content with or without 1.0 g/d of lactoferrin. The largest SEM was $116 \mathrm{~g} / \mathrm{d}$ during weaning (wk 7). $\mathrm{C} 0=$ conventional $\mathrm{MR}, \mathrm{CL}=$ conventional $\mathrm{MR}+1 \mathrm{~g} / \mathrm{d}$ of lactoferrin, $\mathrm{I} 0=28 \% \mathrm{CP} \mathrm{MR}$, and $\mathrm{IL}=$ $28 \% \mathrm{CP} \mathrm{MR}+1 \mathrm{~g} / \mathrm{d}$ of lactoferrin.

the curve for xylose. Glucose absorption was higher at $0,0.5,8$, and $12 \mathrm{~h}$ for intensified-fed calves compared with conventionally fed calves. Glucose area under the curve tended $(P<0.10)$ to be higher for calves fed intensified MR compared with calves fed control MR (Table 6 ).

\section{DISCUSSION}

Overall, starter intake for the intensified-fed calves was around $560 \mathrm{~g} / \mathrm{d}$, with total DMI averaging around $1,432 \mathrm{~g} / \mathrm{d}$. This is higher than observed in a similar study in which calves fed a high-protein MR diet had

Table 3. Body weights, ADG, and gain per DMI for calves fed 2 milk replacers (MR) varying in CP content with or without $1.0 \mathrm{~g} / \mathrm{d}$ of bovine lactoferrin preweaning

\begin{tabular}{|c|c|c|c|c|c|c|c|c|}
\hline \multirow[b]{2}{*}{ Item } & \multicolumn{4}{|c|}{ Treatment $^{1}$} & \multirow[b]{2}{*}{ SEM } & \multicolumn{3}{|c|}{ Contrast $^{2}$} \\
\hline & $\mathrm{C} 0$ & CL & I0 & IL & & $\mathrm{LF}$ & MR & INT \\
\hline \multicolumn{9}{|l|}{ BW (kg) } \\
\hline Initial & 44.2 & 37.6 & 42.5 & 43.3 & - & - & - & - \\
\hline Preweaning & 51.7 & 52.6 & 57.3 & 56.5 & 2.58 & NS & 0.06 & NS \\
\hline Wk 7 (weaning) & 66.8 & 66.0 & 72.2 & 70.6 & 1.46 & NS & $<0.001$ & NS \\
\hline Postweaning & 75.0 & 73.7 & 79.3 & 77.0 & 3.04 & NS & NS & NS \\
\hline \multicolumn{9}{|l|}{ ADG (g/d) } \\
\hline Preweaning & 476.4 & 451.1 & 773.9 & 732.2 & 45.2 & NS & $<0.001$ & NS \\
\hline Wk 7 (weaning) & 654.5 & 634.1 & 152.7 & 80.6 & 133.2 & NS & $<0.001$ & NS \\
\hline Postweaning & 673.7 & 757.6 & 686.6 & 629.5 & 60.5 & NS & NS & NS \\
\hline Overall & 501.3 & 492.8 & 599.5 & 555.0 & 33.9 & NS & 0.03 & NS \\
\hline \multicolumn{9}{|l|}{ Gain/DMI } \\
\hline Preweaning & 0.51 & 0.46 & 0.57 & 0.61 & 0.033 & NS & 0.003 & NS \\
\hline Wk 7 (weaning) & 0.46 & 0.42 & 0.19 & -0.13 & 0.141 & NS & 0.005 & NS \\
\hline Postweaning & 0.36 & 0.39 & 0.42 & 0.43 & 0.033 & NS & NS & NS \\
\hline Overall & 0.39 & 0.37 & 0.41 & 0.41 & 0.017 & NS & NS & NS \\
\hline
\end{tabular}

${ }^{1}$ Treatments: $\mathrm{C} 0=$ conventional $\mathrm{MR}, \mathrm{CL}=$ conventional $\mathrm{MR}+1 \mathrm{~g} / \mathrm{d}$ of lactoferrin, $\mathrm{I} 0=28 \% \mathrm{CP} \mathrm{MR}$, and $\mathrm{IL}=28 \% \mathrm{CP} \mathrm{MR}+1 \mathrm{~g} / \mathrm{d}$ of lactoferrin.

${ }^{2}$ Contrasts: $\mathrm{LF}=$ lactoferrin vs. no lactoferrin; $\mathrm{MR}=$ conventional $\mathrm{MR}$ vs. $28 \% \mathrm{CP} \mathrm{MR}$; and INT = interaction. 


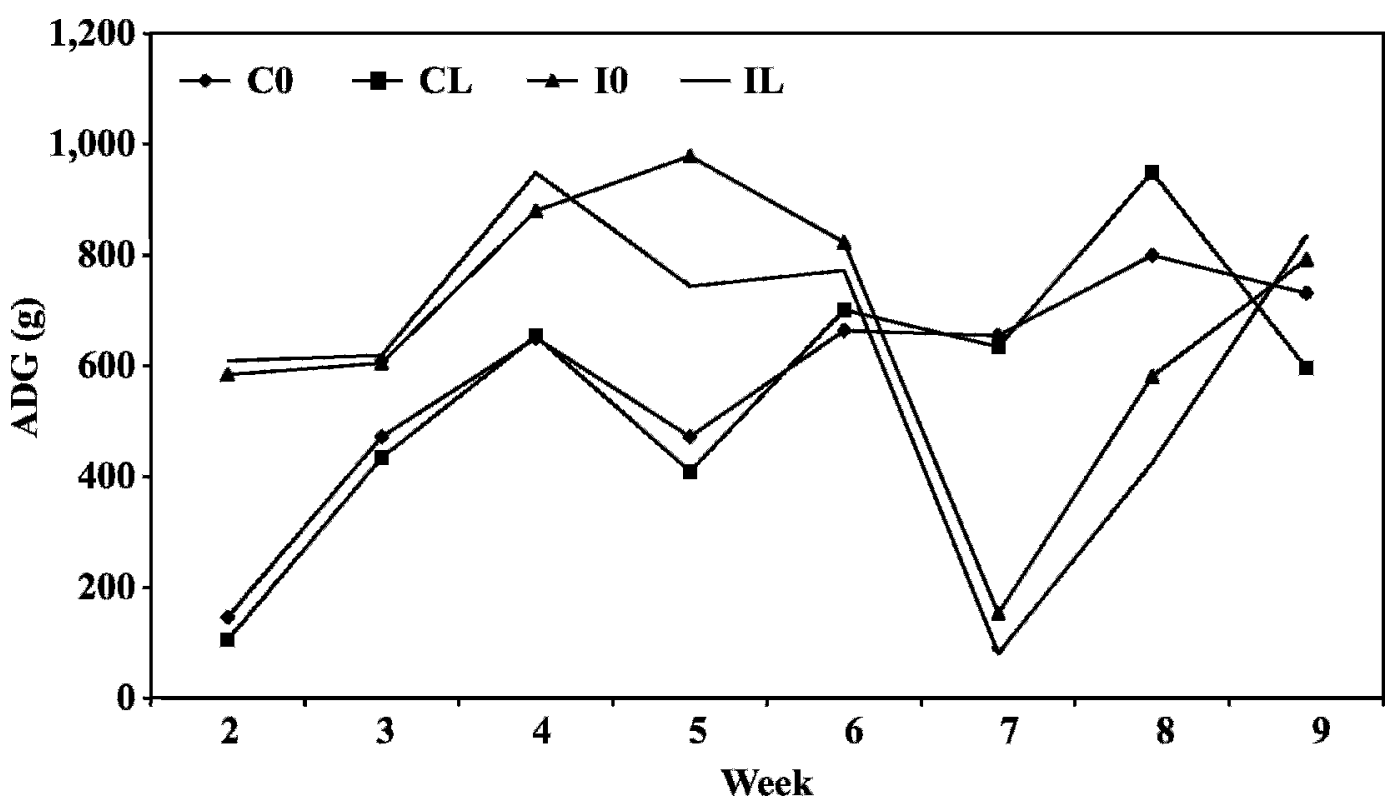

Figure 3. Average daily gain of calves fed 2 milk replacers (MR) varying in CP content with or without $1.0 \mathrm{~g} / \mathrm{d}$ of lactoferrin preweaning. The largest SEM was $188 \mathrm{~g}$ during wk $9 . \mathrm{C} 0=$ conventional $\mathrm{MR}, \mathrm{CL}=$ conventional $\mathrm{MR}+1 \mathrm{~g} / \mathrm{d}$ of lactoferrin, I0 = 28\% $\mathrm{CP} \mathrm{MR}$, and IL = $28 \% \mathrm{CP} M R+1 \mathrm{~g} / \mathrm{d}$ of lactoferrin.

starter intake averaging about $335 \mathrm{~g} / \mathrm{d}$, and total DMI averaging 1,213 g/d (Brown et al., 2005). Intakes were not shown in phases. It should be noted that the present study was 1 wk longer in duration.
Joslin et al. (2002) observed increased starter consumption preweaning in calves fed 1 or $10 \mathrm{~g} / \mathrm{d}$ of LF. This was not observed in the present study. As expected, calves receiving the intensified treatments had higher

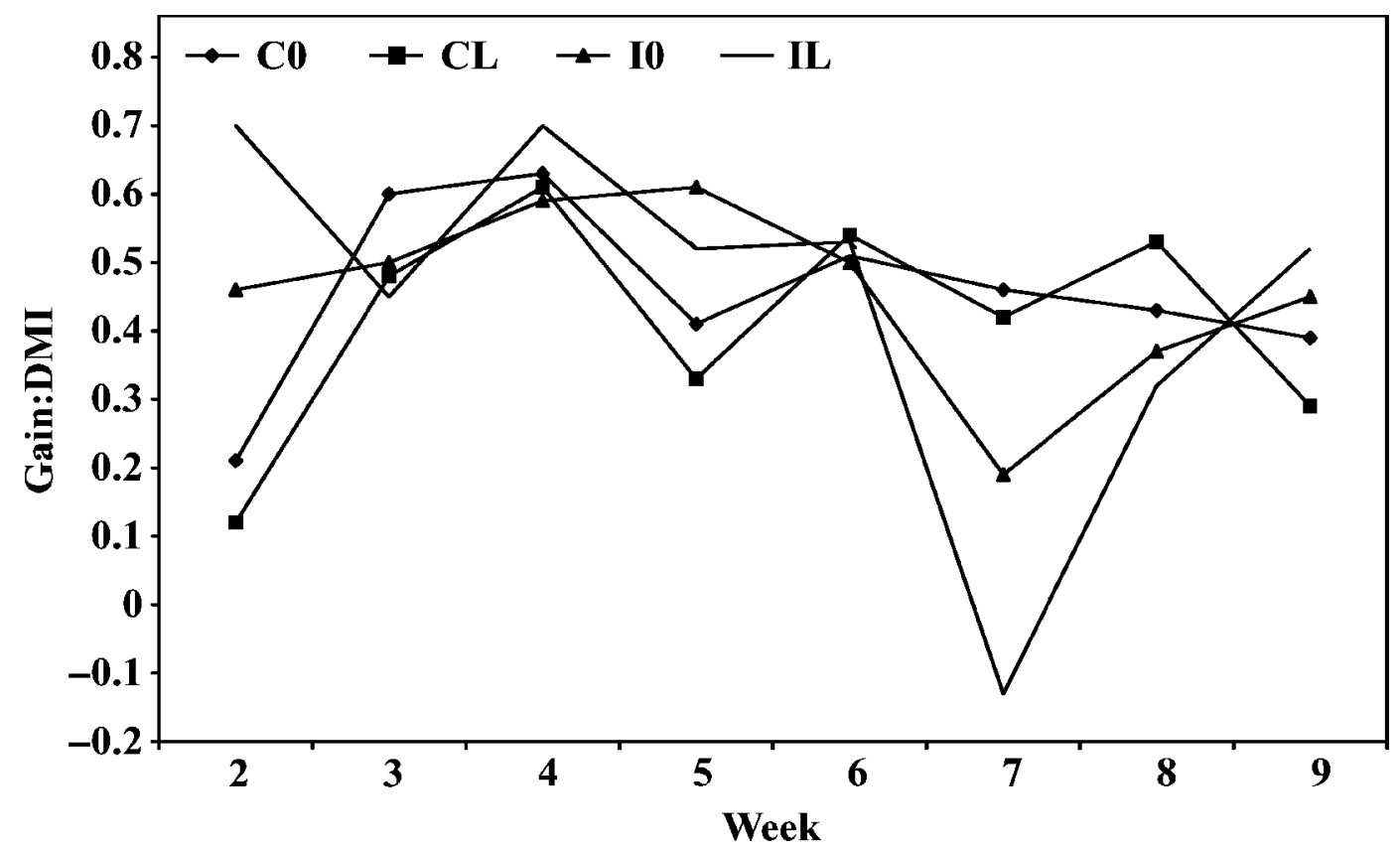

Figure 4. Feeding efficiency of calves fed 2 milk replacers (MR) varying in CP content with or without $1.0 \mathrm{~g} / \mathrm{d}$ of lactoferrin. The largest SEM was 0.14 during weaning (wk 7). $\mathrm{C} 0=$ conventional $\mathrm{MR}, \mathrm{CL}=$ conventional $\mathrm{MR}+1 \mathrm{~g} / \mathrm{d}$ of lactoferrin, $\mathrm{I} 0=28 \% \mathrm{CP} \mathrm{MR}$, and IL $=28 \%$ $\mathrm{CP} M R+1 \mathrm{~g} / \mathrm{d}$ of lactoferrin. 
Table 4. Skeletal measurements for calves fed 2 milk replacers (MR) varying in CP content with or without $1.0 \mathrm{~g} / \mathrm{d}$ of lactoferrin preweaning

\begin{tabular}{|c|c|c|c|c|c|c|c|c|}
\hline \multirow[b]{2}{*}{ Item } & \multicolumn{4}{|c|}{ Treatment $^{1}$} & \multirow[b]{2}{*}{ SEM } & \multicolumn{3}{|c|}{ Contrast $^{2}$} \\
\hline & $\mathrm{C} 0$ & $\mathrm{CL}$ & I0 & IL & & $\mathrm{LF}$ & MR & INT \\
\hline \multicolumn{9}{|c|}{ Withers height $(\mathrm{cm})$} \\
\hline Preweaning & 84.8 & 84.4 & 82.1 & 85.5 & 1.82 & NS & NS & NS \\
\hline Wk 7 (weaning) & 88.5 & 89.2 & 88.6 & 92.1 & 1.19 & 0.08 & NS & NS \\
\hline Postweaning & 91.5 & 89.3 & 91.1 & 92.3 & 1.32 & NS & NS & NS \\
\hline \multicolumn{9}{|l|}{ Hip height $(\mathrm{cm})$} \\
\hline Preweaning & 88.8 & 87.9 & 88.1 & 89.7 & 1.12 & NS & NS & NS \\
\hline Wk 7 (weaning) & 92.8 & 91.0 & 94.1 & 95.6 & 1.49 & NS & 0.04 & NS \\
\hline Postweaning & 94.7 & 92.4 & 95.8 & 96.4 & 1.26 & NS & 0.04 & NS \\
\hline \multicolumn{9}{|l|}{ Heart girth $(\mathrm{cm})$} \\
\hline Preweaning & 86.6 & 85.4 & 89.5 & 90.2 & 1.15 & NS & 0.002 & NS \\
\hline Wk 7 (weaning) & 93.1 & 92.7 & 98.2 & 97.0 & 1.34 & NS & 0.001 & NS \\
\hline Postweaning & 96.9 & 95.9 & 99.7 & 99.3 & 1.52 & NS & 0.05 & NS \\
\hline \multicolumn{9}{|l|}{ Hip width $(\mathrm{cm})$} \\
\hline Preweaning & 27.9 & 27.9 & 28.9 & 29.9 & 0.92 & NS & 0.08 & NS \\
\hline Wk 7 (weaning) & 29.5 & 29.2 & 30.8 & 30.8 & 0.58 & NS & 0.01 & NS \\
\hline Postweaning & 29.9 & 29.9 & 31.4 & 30.7 & 0.53 & NS & 0.04 & NS \\
\hline
\end{tabular}

${ }^{1}$ Treatments: $\mathrm{C} 0=$ conventional $\mathrm{MR}, \mathrm{CL}=$ conventional $\mathrm{MR}+1 \mathrm{~g} / \mathrm{d}$ of lactoferrin, $\mathrm{I} 0=28 \% \mathrm{CP} \mathrm{MR}$, and $\mathrm{IL}=28 \% \mathrm{CP} \mathrm{MR}+1 \mathrm{~g} / \mathrm{d}$ of lactoferrin.

${ }^{2}$ Contrasts: $\mathrm{LF}=$ lactoferrin vs. no lactoferrin; $\mathrm{MR}=$ conventional $\mathrm{MR}$ vs. $28 \% \mathrm{CP} \mathrm{MR}$; and INT = interaction.

total DMI but lower starter intakes. These calves were fed almost at ad libitum liquid intakes, thereby giving the calves no incentive to consume appreciable amounts of dry feed, which is necessary for rumen development (Davis and Drackley, 1998). In contrast, calves on conventional treatments had consistently higher starter intakes from wk 3 until the completion of the study. For consistency purposes, weaning was held constant regardless of the MR fed. In practice, calves fed conventional treatments could have been weaned earlier than 7 wk (Greenwood et al., 1997). Calves fed intensified treatments doubled their starter intake during weaning, but on average it was $50 \%$ of the starter intake that the conventionally fed calves were consuming. Postweaning, there was a difference in DMI, but all calves were eating appreciable amounts of starter.

There was an MR effect on BW; intensified-fed calves were heavier during the preweaning and weaning phases. Previous research has shown that intensifiedfed calves are heavier than those raised conventionally (Diaz et al., 2001; Blome et al., 2003; Brown et al., 2005). Calves on this study did not maintain the weight advantage postweaning. This may be an example of compensatory growth occurring with the restricted-fed heifers (Lacasse et al., 1994). This response is similar to older heifers raised in a stair-step regimen (Ford

Table 5. Days medicated and fecal scores of calves fed 2 milk replacers (MR) varying in CP content with or without $1.0 \mathrm{~g} / \mathrm{d}$ of bovine lactoferrin preweaning

\begin{tabular}{|c|c|c|c|c|c|c|c|c|}
\hline \multirow[b]{2}{*}{ Item } & \multicolumn{4}{|c|}{ Treatment $^{1}$} & \multirow[b]{2}{*}{ SEM } & \multicolumn{3}{|c|}{ Contrast $^{2}$} \\
\hline & $\mathrm{CO}$ & $\mathrm{CL}$ & I0 & IL & & $\mathrm{LF}$ & MR & INT \\
\hline \multicolumn{9}{|l|}{ Days medicated } \\
\hline Preweaning & 0.88 & 1.89 & 2.56 & 2.86 & 0.60 & $\mathrm{NS}^{3}$ & 0.02 & NS \\
\hline Wk 7 (weaning) & 0.63 & 0 & 0.44 & 0.43 & 0.46 & NS & NS & NS \\
\hline Postweaning & 0 & 0 & 0 & 0 & 0 & $\mathrm{NS}$ & NS & NS \\
\hline Overall & 1.50 & 1.89 & 3.11 & 3.29 & 0.78 & NS & 0.05 & NS \\
\hline \multicolumn{9}{|l|}{ Fecal scores } \\
\hline Preweaning & 2.5 & 2.6 & 2.6 & 2.6 & 0.05 & NS & NS & NS \\
\hline Wk 7 (weaning) & 2.6 & 2.5 & 2.4 & 2.2 & 0.11 & $\mathrm{NS}$ & 0.04 & NS \\
\hline Postweaning & 2.5 & 2.5 & 2.6 & 2.5 & 0.11 & NS & NS & NS \\
\hline Overall & 2.5 & 2.6 & 2.6 & 2.5 & 0.05 & NS & NS & NS \\
\hline
\end{tabular}

\footnotetext{
${ }^{1}$ Treatments: $\mathrm{C} 0=$ conventional $\mathrm{MR}, \mathrm{CL}=$ conventional $\mathrm{MR}+1 \mathrm{~g} / \mathrm{d}$ of lactoferrin, $\mathrm{I} 0=28 \% \mathrm{CP} \mathrm{MR}$, and $\mathrm{IL}=28 \% \mathrm{CP} \mathrm{MR}+1 \mathrm{~g} / \mathrm{d}$ of lactoferrin.

${ }^{2}$ Contrasts: $\mathrm{LF}=$ lactoferrin vs. no lactoferrin; $\mathrm{MR}=$ conventional $\mathrm{MR}$ vs. $28 \% \mathrm{CP} \mathrm{MR}$; and INT = interaction.
} 
Table 6. Blood urea concentrations, xylose, and glucose concentration from d-10 xylose challenge for calves fed 2 milk replacers (MR) varying in CP content with or without $1.0 \mathrm{~g} / \mathrm{d}$ of bovine lactoferrin (LF) preweaning

\begin{tabular}{|c|c|c|c|c|c|c|c|c|}
\hline \multirow[b]{2}{*}{ Item } & \multicolumn{4}{|c|}{ Treatment $^{1}$} & \multirow[b]{2}{*}{ SEM } & \multicolumn{3}{|c|}{ Contrast $^{2}$} \\
\hline & $\mathrm{C} 0$ & CL & I0 & IL & & $\mathrm{LF}$ & MR & INT \\
\hline \multicolumn{9}{|l|}{ BUN (mg/dL) } \\
\hline Preweaning & 16.0 & 17.4 & 14.6 & 15.2 & 0.81 & NS & 0.03 & NS \\
\hline Wk 7 (weaning) & 22.0 & 23.9 & 22.8 & 22.5 & 1.85 & NS & NS & NS \\
\hline Postweaning & 24.0 & 24.9 & 22.9 & 28.6 & 1.90 & 0.07 & NS & NS \\
\hline Overall & 17.8 & 19.3 & 17.0 & 18.2 & 0.89 & NS & NS & NS \\
\hline $\begin{array}{l}\text { Xylose AUC } \\
(\mathrm{mmol} / \mathrm{L} \text { per h) }\end{array}$ & 30.67 & 25.35 & 30.01 & 21.74 & 6.13 & NS & NS & NS \\
\hline $\begin{array}{l}\text { Glucose AUC } \\
(\mathrm{mg} / \mathrm{dL} \text { per } \mathrm{h})\end{array}$ & 1,130 & 1,176 & 1,067 & 1,192 & 56.5 & NS & 0.08 & NS \\
\hline
\end{tabular}

\footnotetext{
${ }^{1}$ Treatments: $\mathrm{C} 0=$ conventional $\mathrm{MR}, \mathrm{CL}=$ conventional $\mathrm{MR}+1 \mathrm{~g} / \mathrm{d}$ of lactoferrin, $\mathrm{I} 0=28 \% \mathrm{CP} \mathrm{MR}$, and $\mathrm{IL}=28 \% \mathrm{CP} \mathrm{MR}+1 \mathrm{~g} / \mathrm{d}$ of lactoferrin.

${ }^{2}$ Contrasts: $\mathrm{LF}=$ lactoferrin vs. no lactoferrin; $\mathrm{MR}=$ conventional $\mathrm{MR}$ vs. $28 \% \mathrm{CP} \mathrm{MR}$; and INT = interaction.

${ }^{3} \mathrm{AUC}=$ Area under the curve.
}

and Park, 2001). After inducing compensatory growth during an allometric phase of growth, mammary gland development and energy and protein metabolic status were improved (Ford and Park, 2001). Even though the conventionally fed heifers were not capitalizing on early, fast growth, they were able to compensate in BW by $\mathrm{d} 63$.

The MR effect on ADG seen preweaning was a function of higher total DMI and heavier BW for the calves fed intensified treatments. The effect was reversed during weaning; calves fed conventional treatments had a 5 -fold increase in ADG over calves on the intensified treatments. This can be attributed to the $50 \%$ decrease in MR fed during weaning, coupled with lower starter intakes compared with conventionally fed calves. Joslin et al. (2002) observed an increase in ADG preweaning when calves were fed either dose of 1 or $10 \mathrm{~g} / \mathrm{d}$ of LF. Robblee et al. (2003) saw a linear effect of LF on preweaning ADG with calves fed 1,2 , or $3 \mathrm{~g} / \mathrm{d}$ of LF. This effect of LF was not apparent in this experiment.

Young animals are very efficient at converting dietary protein to body protein. In support of research with young nonruminant animals and with ruminants raised on this intensified regimen (Diaz et al., 2001; Blome et al., 2003), calves on the intensified treatments had increased ADG per DMI preweaning. During weaning, calves receiving conventional treatments were more efficient, reflecting the decrease in ADG and DMI of the calves on the intensified treatments. An intensified MR program may not have value if calves lose the effects of gains and efficiencies acquired preweaning after weaning.

In contrast to the current study in which LF had no effect ADG per DMI, Robblee et al. (2003) observed a linear effect on ADG per DMI with increasing amounts of LF. Humphrey et al. (2002) saw increased ADG per
DMI in chicks fed LF compared with control chicks, and that equaled the antibiotic treatment used in their experiment. This was not seen in this study.

Joslin et al. (2002) and Robblee et al. (2003) observed increase heart girth gain for calves fed LF. In the present study, there was a trend for increased wither height gain in calves fed LF. There is no explanation for this effect because BW, ADG, and feed efficiency were unaffected by LF addition. The effects on skeletal growth are reflective of the increase in frame size seen with calves fed on the intensified-fed program. Calves fed the intensified treatments were taller at the hip, had larger heart girths, and larger hip widths. Increased skeletal growth is more important than increased BW; one of the goals of an intensified heifer-raising program is to reduce the age at first breeding, which is directly related to frame size (Heinrichs and Hargrove, 1987). There was a trend for the interaction for average daily hip width gain overall but there is no clear explanation for this.

Robblee et al. (2003) observed a quadratic effect on fecal scores and days medicated. Calves fed $1 \mathrm{~g} / \mathrm{d}$ of LF had the lowest preweaning fecal scores and number of days medicated. There was no effect on fecal scores or days medicated in the current study. This supports the findings of Joslin et al. (2002). Based on the previous research conducted in our laboratory, it is surprising that fecal scores and days medicated were not affected by LF. This may be due to the fact that preweaning fecal scores and days medicated were at least $50 \%$ lower that than reported by Joslin et al. (2002). The overall days medicated in the current study from the CL treatment compared with the $1 \mathrm{~g} / \mathrm{d}$ of LF from Robblee et al. (2003) were slightly higher (1.89 vs. 1.59 , respectively). There was an MR effect on both preweaning and overall days medicated, with calves receiving the intensified 
MR having more days medicated than those on conventional treatments. It would be expected that a similar effect would be seen in fecal scores, but this was not observed. This may be because fecal scores were only recorded 3 times weekly, but the calves could be medicated any time during the week. The MR effect seen during weaning of conventionally fed calves having higher fecal scores may be explained by the fact that the calves at this point were eating an average of 1,256 $\mathrm{g}$ of starter compared with the intensified-fed calves eating an average of $635 \mathrm{~g}$ of starter. Because these calves could have been weaned much earlier and would have been started on a TMR, it is possible that they had mild acidosis, causing some diarrhea. These calves, however, had no further challenges postweaning.

There was no effect of LF on xylose and glucose absorption. Xylose absorption is used as an indirect method to estimate intestinal epithelial size and function (Hammon and Blum, 1997; Kuhne et al., 2000; Rauprich et al., 2000). Previous research with other species indicates that LF has a stimulatory effect on both cell proliferation and increased cell size (Zhang et al., 2001). Zhang et al. (2001) found oral LF increased small intestine size in rat pups. Humphrey et al. (2002) observed increased villus heights in the duodenum of chicks fed rice expressing LF and lysozyme. Results from this study do not support this characteristic of LF in the preruminant calf.

Some of the calves were experiencing slight diarrhea during the xylose challenge, likely impairing the absorptive ability of the small intestine. Xylose is used to determine the health of the small intestine. Diarrhea affects the absorption of nutrients and may mask the true absorptive capacity of the cells. Because calves fed intensified MR consumed greater amounts of both lactose and protein than the conventionally fed calves due to greater DMI, they would be expected to have increased glucose levels compared with conventionally fed calves.

As a sign of excess protein, BUN concentrations were originally determined to observe differences between the $\mathrm{CP}$ of the diets and circulating $\mathrm{N}$. Because calves on intensified treatments had lower serum urea preweaning, excess protein can be excluded.

It is also possible that calves receiving conventional treatments had more endogenous protein breakdown than intensified-fed calves. It has been reported than in piglets fed water, colostrum, or milk, fractional protein synthesis in the visceral organs was 3- to 4-fold greater in the piglets fed milk or colostrum (Burrin et al., 1992). Perhaps the intensified-fed calves had greater protein synthesis relative to protein ingestion than the conventionally fed calves, which may explain the increased preweaning urea levels in the conventionally fed calves.
Some of the differences seen are also indicative of rumen development. There are better indicators, such as BHBA concentrations, of the conversion of the rumen from immature to mature, such as VFA production and microbial protein synthesis. However, urea $\mathrm{N}$ may be an indirect measurement of ammonia production in the rumen. Abdelgadir et al. (1996) noted that in calves receiving more RDP in their diet had higher ruminal ammonia than those with lower RDP diets. Calves consuming conventional treatments were consuming significantly more starter grain, which contained $16.3 \%$ RDP and 8.6\% RUP (DM basis). This may explain why calves receiving conventional treatments had higher preweaning BUN values.

\section{CONCLUSIONS}

In conclusion, feeding a higher protein MR in greater volumes compared with a traditional MR resulted in larger calves both preweaning and postweaning. Calves fed intensified treatments consumed less starter throughout the study. Average daily gains were higher for calves fed the intensified treatments preweaning, but were higher for calves fed conventional treatments during weaning. Lactoferrin supplementation in MR fed to preweaned dairy heifers was not beneficial in this experiment. No differences were seen for intestinal absorption. Days medicated were higher for calves fed the intensified treatments, but no differences were seen for fecal scores. The preweaning period seems to offer potential for increasing growth rates, but calves may have depressed starter intakes when raised on an intensified program. Producers should evaluate their heiferraising goals to decide if intensified feeding programs will work on their operation.

\section{ACKNOWLEDGMENTS}

We would like to thank Archer Daniels Midland Inc., Ft. Wayne, IN, for donating the calf starter used in the experiment. We would also like to thank ImmuCell Corporation, Portland, ME, for donating the lactoferrin and Land O'Lakes, Inc., St. Paul, MN, for financial support. We would also like to thank Ryan Ordway for his time spent performing fecal scoring, Wenping $\mathrm{Hu}$, University of Illinois, for performing bomb calorimetry on the milk replacer, Michael Van Amburgh, Cornell University, and Charles Schwab, University of New Hampshire, for their input in designing the experiment. Lastly, we would like to thank the staff at the Fairchild Dairy Teaching and Research Center for caring for the calves and Celeste Dietterle for typing the manuscript. 


\section{REFERENCES}

Abdelgadir, I. E. O., J. L. Morrill, and J. J. Higgins. 1996. Effect of roasted soybeans and corn on performance and ruminal and blood metabolites of dairy calves. J. Dairy Sci. 79:465-474.

AOAC. 1979. Protein (crude) in animal feed semiautomated method 976.06. J. AOAC 62:290.

AOAC. 1990. Official Methods of Analysis. 15th ed. Association of Official Analytical Chemists, Washington, DC.

AOAC. 1995. Official Methods of Analysis. 16th ed. Association of Official Analytical Chemists, Washington, DC.

Blome, R. M., J. K. Drackley, F. K. Keith, M. F. Hutjens, and G. C. McCoy. 2003. Growth, nutrient utilization, and body composition of dairy calves fed milk replacers fed different amounts of protein. J. Anim. Sci. 81:1641-1655.

Brown, E. G., M. J. VandeHaar, K. M. Daniels, J. S. Liesman, L. T. Chapin, D. H. Keiser, and M. S. Weber-Nielsen. 2005. Effect of increasing energy and protein intake on body growth and carcass composition of heifer calves. J. Dairy Sci. 88:585-594.

Burrin, D. G., R. J. Shulman, P. J. Reeds, T. A. Davis, and K. R. Gravitt. 1992. Porcine colostrum and milk stimulate visceral organ and skeletal muscle protein synthesis in neonatal piglets. J. Nutr. 122:1205-1213.

Davis, C. L., and J. K. Drackley. 1998. The Development, Nutrition, and Management of the Young Calf. 1st ed. Iowa State University Press, Ames.

Diaz, M. C., M. E. Van Amburgh, J. M. Smith, J. M. Kelsey, and E. L. Hutten. 2001. Composition of growth of Holstein calves fed milk replacer from birth to 105-kilogram body weight. J. Dairy Sci. 84:830-842.

Ford, J. A., and C. S. Park. 2001. Nutritionally directed compensatory growth enhances heifer development and lactation potential. J. Dairy Sci. 84:1669-1678.

Goering, H. K., and P. J. Van Soest. 1970. Forage Fiber Analysis (Apparatus, Reagents, Procedures, and Some Applications). Agric. Handbook No. 379. ARS-USDA, Washington, DC.

Greenwood, R. H., J. L. Morrill, and E. C. Titgemeyer. 1997. Using dry feed intake as a percentage of initial body weight as a weaning criterion. J. Dairy Sci. 80:2542-2546.

Hammon, H., and J. W. Blum. 1997. Prolonged colostrum feeding enhances xylose absorption in neonatal calves. J. Anim. Sci. 75:2915-2919

Heinrichs, A. J., and G. L. Hargrove. 1987. Standards of weight and height for Holstein heifers. J. Dairy Sci. 70:653

Humphrey, B. D., N. Huang, and K. C. Klasing. 2002. Rice expressing lactoferrin and lysozyme has antibiotic-like properties when fed to chicks. J. Nutr. 132:1214-1218.

Joslin, R. S., P. S. Erickson, H. M. Santoro, N. L. Whitehouse, C. G. Schwab, and J. J. Rejman. 2002. Lactoferrin supplementation to dairy calves. J. Dairy Sci. 85:1237-1242.
Kijlstra, A., S. H. Jeurissen, and K. M. Koning. 1983. Lactoferrin levels in normal human tears. Br. J. Ophthamol. 67:199-202.

Kuhne, S., H. M. Hammon, R. M. Bruckmaier, C. Morel, Y. Zbinden, and J. W. Blum. 2000. Growth performance, metabolic and endocrine traits and absorptive capacity in neonatal calves fed either colostrum or milk replacer at two different levels. J. Anim. Sci. 78:609-620.

LaCasse, P., E. Block, and D. Peticlerc. 1994. Effect of plane of nutrition before and during gestation on the concentration of hormones in dairy heifers. J. Dairy Sci. 77:439-445.

Masson, P. L., and J. F. Heremans. 1971. Lactoferrin in milk from different species. Comp. Biochem. Physiol. 39B:119-129.

Merritt, A. M., and P. Duelly. 1983. Phloroglucinol microassay for plasma xylose in dogs and horses. Am. J. Vet. Res. 44:2184-2185.

National Animal Health Monitoring System. 1996. Dairy herd management practices focusing on preweaned heifers. USDA, Animal and Plant Health Inspection Service, Veterinary Services, Fort Collins, CO.

National Research Council. 2001. Nutrient Requirements of Dairy Cattle. 7th rev. ed. Natl. Acad. Sci., Washington, DC.

Rauprich, A. B. E., H. M. Hammon, and J. W. Blum. 2000. Effects of feeding colostrum and a formula with nutrients as colostrum and a formula and endocrine traits in neonatal calves. Biol. Neonate 78:53-64.

Reiter, B., and J. P. Perraudin. 1998. The antibacterial activity of lactoferrin and neonatal $E$. coli infections. Pages $175-188$ in Advances in Lactoferrin Research. G. Spik, D. Legrand, J. Mazur, and J. P. Perraudin, ed. Plenum Press, New York, NY.

Robblee, E. D., P. S. Erickson, N. L. Whitehouse, A. M. McLaughlin, C. G. Schwab, J. J. Rejman, and R. E. Rompala. 2003. Supplemental lactoferrin improves health and growth of Holstein calves during the preweaning phase. J. Dairy Sci. 86:1458-1464.

SAS Institute. 2001. SAS/STAT User's Guide. Version 8.2 ed. SAS Institute, Inc., Cary, NC.

Talukder, J. R., T. Takeuchi, and E. Harada. 2003. Receptor-mediated transport of lactoferrin into the cerebrospinal fluid via plasma in young calves. J. Vet. Med. Sci. 65:957-964.

Teraguchi, S. T., Ogata, K., Shin, M. Kingaku, Y. Fukawatari, K. Kawase, H. Haysawa, M. Tomita. 1998. The mechanism of in vivo bacteriostasis of bovine lactoferrin. Adv. Exp. Med. Biol. 443:239-246.

Tikofsky, J. N., M. E. Van Amburgh, and D. A. Ross. 2001. Effect of varying carbohydrate and fat content of milk replacer on body composition of Holstein bull calves. J. Anim. Sci. 79:2260-2267.

Weinberg, E. D. 2001. Human lactoferrin: A novel therapeutic with broad spectrum potential. J. Pharm. Pharmacol. 53:1303-1310.

Zhang, P., V. Sawicki, L. Hanson, J. H. Nuijens, and M. C. Neville. 2001. Human lactoferrin in the milk of transgenic mice increases intestinal growth in ten-day-old suckling neonates. Adv. Exp. Med. Biol. 501:107-113. 